\title{
Status keluhan penyakit kulit santri Pesantren Al Ikhlas, Kabupaten Bone, Provinsi Sulawesi Selatan
}

\author{
Fhirastika Annisha Helvian*, Andi Irhamnia Sakinah, Andi Faradilah \\ Prodi Pendidikan Dokter, Fakultas Kedokteran dan Ilmu Kesehatan, UIN Alauddin Makassar \\ E-mail : fhirastika.annisha@uin-alauddin.ac.id
}

\begin{abstract}
Abstrak
Keluhan kulit merupakan keluhan yang paling banyak ditemukan pada anak pesantren. Faktor higienitas memegang peranan penting dalam munculnya penyakit kulit di pesantren. Pada kegiatan pengabdian masyarakat Prodi Pendidikan Dokter Fakultas Kedokteran dan Ilmu Kesehatan, kami bertujuan melakukan pemeriksaan serta intervensi pengobatan dan penyuluhan terkait penyakit kulit yang sering ditemukan pada santri pesantren. Kegiatan pengabdian masyarakat dilaksanakan pada 96 santri pesantren yang kesemuanya mengikuti semua tahapan yaitu penyuluhan, pemeriksaan kulit, dan pengobatan. Keluhan gatal mencapai prevalensi $87,5 \%$ diutarakan oleh santri pesantren sedangkan keluhan berupa kutu rambut dan ketombe dominan hanya dinyatakan oleh santri perempuan (santriwati). Keluhan penyakit kulit masih menjadi keluhan yang sering terjadi di kalangan santri pesantren. Kegiatan pengabdian masyarakat pada pesantren dengan mengambil tema penyakit kulit dan kelamin perlu terus digalakkan.
\end{abstract}

Kata kunci: Pesantren, Penyakit Kulit, Gatal.

\begin{abstract}
The status of skin diseases complaints of the students at the Al Ikhlas Islamic Boarding School, Bone Regency, South Sulawesi Province. Skin diseases are the most common problems among students. Hygiene factors play an important role in the emergence of skin diseases in Islamic boarding schools. In the community service activities of the Medical Education Study Program of the Faculty of Medicine and Health Sciences, we aim to carry out examinations and interventions for treatment and counseling related to skin diseases that are often found in students of Islamic boarding school. Community service activities were carried out on 96 students who all followed all stages, namely counseling, skin examinations, and treatment. The complaints of itching reaching a prevalence of $87.5 \%$ were expressed by students while complaints in the form of head lice and dandruff were dominant only by female students (santriwati). Complaints of skin disease are still a frequent complaint among students of Islamic boarding school. Community service activities at Islamic boarding school with the theme of skin and venereal diseases need to be more encouraged.
\end{abstract}

Keywords: Islamic Boarding School, Skin Disease, Itch.

\section{PENDAHULUAN}

Pesantren Al-Ikhlas Ujung Bone, Sulawesi Selatan bernaung di bawah Yayasan Al-Ikhlas Bone yang didirikan pada tanggal 18 September 2000 M, bertepatan tanggal 19 Jumadil 
Akhir $1421 \mathrm{H}$. Pesantren ini didirikan sebagai wujud keprihatinan terhadap kualitas dan kuantitas pendidikan di dalam masyarakat, yang menuntut sumber daya manusia yang handal di masa depan. Selain memiliki lembaga kepondokan yang membidangi pendidikan keagamaan santri dan pengembangan karakter melalui pembinaan kehidupan kepesantrenan secara total, Yayasan Al-Ikhlas bone juga memiliki Madrasah Aliyah, Madrasah Tsanawiyah, Raudatul Athfal dan Taman Pendidikan Alqur'an.

Pondok pesantren ini memiliki sarana dan fasilitas yang cukup baik dengan 55 ruang kamar santri dan 132 ruang mandi-cuci-kakus (MCK), namun kebiasaan santri yang masih kurang memperhatikan perilaku hidup bersih dan sehat berdampak pada banyaknya keluhan kesehatan yang berhubungan dengan penyakit kulit. Dalam sebuah sesi diskusi, banyak santri yang mengeluhkan tentang gatal-gatal di kepala, badan, bahkan di daerah selangkangan yang sering hilang timbul dan berulang. Pondok ini memiliki pos kesehatan pesantren (poskestren) tempat santri sering berobat, namun upaya kesehatan kuratif tanpa promotif dan preventif diduga menjadi penyebab keluhan sering berulang.

Pengabdian masyarakat berupa penyuluhan dan pemeriksaan kesehatan kulit bagi santri dianggap sebagai alat promotif dan preventif yang cukup efektif. Edukasi tentang beberapa penyakit kulit yang dapat timbul pada santri disertai dengan cara pencegahannya diharapkan dapat meningkatkan kesadaran santri tentang perilaku hidup bersih dan sehat. Selain itu, pemeriksaan kesehatan dan pengobatan yang diberikan diharapkan juga menjadi upaya kuratif dan rehabilitatif dalam menurunkan angka kejadian penyakit kulit di Pondok Pesantren Al-Ikhlas Ujung Bone.

\section{TINJAUAN PUSTAKA}

Merujuk pada Pangkalan Data Pendidikan Pondok Pesantren, Indonesia memiliki total jumlah pesantren mencapai 27.722 lembaga dengan jumlah santri sebanyak 4.175.457 orang. Dalam satu pondok pesantren jumlah santri berkisar antara 200-1000 santri yang tinggal bersama dalam kurun waktu tertentu. ${ }^{1}$ Pondok pesantren merupakan lembaga pendidikan 
keagamaan islam berbasis masyarakat yang menyelengarakan pendidikan secara terpadu dengan jenis pendidikan lain yang dilakukan secara formal maupun informal. ${ }^{2}$

Akibat arus globalisasi saat ini, banyak bermunculan berbagai model-model pondok pesantren era milenial. Berbagai pengembangan dilakukan, diantaranya penguasaan bahasa asing, enterpreunership, ICT (Information and Communication Technology), serta kompetensi kekinian lainnya. ${ }^{3}$ Namun dari sudut pandang medis modern, respon santri terhadap perilaku kesehatan masih kurang diperhatikan. Dalam menjaga dan memelihara kesehatan santri masih menggunakan cara yang sederhana yaitu beristirahat dan mencari pengobatan di sekitar pondok tanpa tenaga profesional. Beberapa santri juga berusaha mengobati dirinya sendiri dengan membeli obat di koperasi pondok atau apotek. ${ }^{4}$

Selain itu, perilaku kesehatan yang dilakukan santri dipengaruhi oleh struktur dan nilai-nilai budaya serta nilai religi yang berlaku di pesantren. Usaha rasionalisasi perilaku hidup bersih dan sehat (PHBS) juga masih menyesuaikan dengan nilai-nilai dan kultural tersebut. ${ }^{4}$ Akses pelayanan kesehatan, kesehatan lingkungan dan perilaku hidup sehat masih dianggap perlu mendapat perhatian yang dalam pada pondok pesantren. ${ }^{5}$ Salah satu penyakit yang sering timbul akibat rendahnya perilaku hidup bersih dan sehat adalah penyakit kulit. ${ }^{6}$

Salah satu kondisi dermatologis yang paling umum di negara berkembang saat ini adalah skabies. Menurut WHO tahun 2017, estimasi prevalensi dalam literatur terkait skabies berkisar dari $0,2 \%-71 \%$. Skabies dianggap penyakit endemik di daerah tropis miskin dan berpenghasilan rendah, dengan perkiraan prevalensi pada anak rata-rata 5-10\% dengan manifestasi yang sering berulang. ${ }^{7}$ Berdasarkan sebuah literatur, ada beberapa faktor yang dapat mempengaruhi terjadinya skabies, yaitu jenis kelamin, usia, perilaku, sikap, pengetahuan, kelembaban udara, kepadatan penghuni,vebtilasi, suhu, dan pencahayaan alami. ${ }^{8}$ Penularan skabies terjadi secara kontak langsung manusia ke manusia. Penularan tertinggi pada manusia terjadi pada kelompok masyarakat yang hidup 
berhimpitan seperti di asrama, rumah jompo, pesantren, barak militer dan tempat lain dengan kondisi lingkungan dan hygiene perorangan yang buruk. ${ }^{9}$

Selain skabies, pedikulosis kapitis juga sering menyerang anak-anak usia antara 312 tahun. Kutu kepala dapat menginfestasi semua level masyarakat pada semua etnis. Transmisi terjadi secara kontak kepala ke kepala secara langsung melalui sisir, sikat, pengering rambut, bantal, sprei atau penutup kepala lainnya. ${ }^{10} \mathrm{Kutu}$ kepala menginfestasi lebih dari 100 juta orang di seluruh dunia dengan prevalensi yang bervariasi antara 0,7-76\% pada berbagai lingkungan dengan kebanyakan kasus terjadi pada anak berjenis kelamin perempuan. ${ }^{11}$

\section{METODE}

Kegiatan pengabdian masyarakat dilaksanakan pada Pesantren Al Ikhlas, Kabupaten Bone, Sulawesi Selatan berupa pemeriksaan, pengobatan, serta penyuluhan penyakit kulit dan kelamin pada santri pesantren. Pengambilan data kuesioner dilakukan terhadap 96 santri berupa jenis kelamin, umur, dan indeks massa tubuh. Pada pemeriksaan status kulit dan kelamin dilakukan anamnesis keluhan utama penyakit kulit dan kelamin yang diklasifikasikan menjadi gatal, kulit kemerahan, kulit bersisik, bisul, kutu rambut, dan ketombe. Karakteristik responden disajikan dalam bentuk nilai rata-rata dan jumlah (n)/persentase. Hubungan antara variabel diuji dengan uji Pearson Chi Square dan disajikan dalam bentuk jumlah (n)/persentase.

\section{HASIL DAN PEMBAHASAN}

Kegiatan pengabdian masyarakat ini bertujuan untuk melakukan pemeriksaan status gizi dan penyakit kulit kelamin. Intervensi yang dilakukan berupa pemberian penyuluhan dan pengobatan terkait penyakit kulit dan kelamin dengan sasaran santri Pesantren Al Ikhlas Bone. Hasil luaran kegiatan ini yakni berupa gambaran karakteristik santri pesantren, status gizi, dan status keluhan penyakit kulit dan kelamin. 
Dari 96 santri yang menjadi peserta dalam kegiatan ini, didapatkan jumlah santri laki-laki dan santri perempuan yang diteliti hampir sama. Selain itu, indeks massa tubuh (IMT) pada santri laki-laki dan santri perempuan tidak berbeda jauh yaitu sebesar $20.61 \pm$ 1.53 dan $19.15 \pm 4.65$. Nilai ini masih berkisar dalam rentang nilai status gizi normal berdasarkan IMT menurut umur.

Dari hasil autoanamnesis dengan kuesioner diperoleh informasi bahwa keluhan gatal dan kemerahan pada kulit menjadi keluhan yang terbanyak (87.5\%; 62.5\%) disebutkan oleh santri pesantren. Penelitian ini sejalan arahnya dengan prevalensi kejadian penyakit kulit-yang diketahui memiliki keluhan gatal dan/atau kemerahan - yang sering terjadi di lingkungan pondok pesantren seperti dermatitis ${ }^{12}$, scabies ${ }^{12-14}$, dan pediculosis capitis ${ }^{15}$. Adriansyah dalam penelitiannya di suatu pesantren di Surabaya menemukan sebanyak 25,5\% santri mengalami scabies dan 6,4\% santri sering mengalami dermatitis. ${ }^{12}$ Tingginya prevalensi kasus ini juga didukung oleh penelitian Ni'mah di salah satu pesantren di Bantul Yogyakarta dengan 74,3\% ${ }^{13}$ dan Aisyah di Pondok Pesantren Al-Aziziyah sebesar 83,3\% ${ }^{14}$ santri yang pernah/sedang mengalami scabies.

Keluhan gatal sebagai manifestasi klinis penyakit kulit dapat disebabkan oleh banyak hal seperti infestasi, inflamasi, infeksi, malignansi, dan penyebab lainnya. Penyebab paling banyak ditemukan yakni infestasi dan inflamasi. Infestasi tersering yakni akibat scabies dan pediculosis, sedangkan inflamasi paling banyak disebabkan adalah dermatitis. ${ }^{16}$ Sebagai salah satu penyakit kulit tersering di Indonesia, scabies merupakan penyakit menular yang insidensinya berkaitan dengan daerah dengan tingkat kebersihan yang rendah serta kepadatan hunian yang memudahkan kontak fisik antarindividu yang mendukung transmisi dan infestasi tungau ${ }^{17}$, seperti asrama, panti asuhan, pondok pesantren, penjara, dan pengungsian. ${ }^{18}$

Sebagai penyakit menular, scabies dapat dicegah dengan meningkatkan kebersihan pribadi dan lingkungan, seperti kebiasaan rutin mencuci tangan, memotong kuku, mandi dua kali sehari dengan sabun, menyetrika pakaian, menggunakan handuk kering, serta 
menjemur kasur di bawah terik sinar matahari minimal 1x seminggu. ${ }^{18}$ Kebiasaan pola hidup bersih dan sehat yang sering kurang diperhatikan seperti ini sejalan dengan hasil penelitian oleh Machfutra dkk. yang menemukan cukup padatnya kondisi kamar santri di suatu pesantren di Yogyakarta yang sering ditinggalkan dalam keadaan berantakan dan cenderung bersifat tak acuh dengan kebersihan dan kerapian kamar. ${ }^{19}$

Tabel 1. Karakteristik responden santri Pesantren Al Ikhlas Bone

\begin{tabular}{lc}
\hline Variabel & \\
\hline Umur (mean \pm SD) & $13.39 \pm 1.57$ \\
Jenis Kelamin & \\
Laki-laki (n,\%) & $46(47.9)$ \\
Perempuan(n,\%) & $50(52.1)$ \\
IMT (mean \pm SD) & $19.85 \pm 4.56$ \\
Keluhan yang Berhubungan Kulit \& Kelamin & \\
Gatal & \\
Ya (n,\%) & $84(87.5)$ \\
Tidak (n,\%) & $12(12.5)$ \\
Kemerahan & \\
Ya (n,\%) & $60(62.5)$ \\
Tidak (n,\%) & $36(37.5)$ \\
Kulit bersisik & \\
Ya (n,\%) & $47(49.0)$ \\
Tidak (n,\%) & $49(51.0)$ \\
Bisul & \\
Ya (n,\%) & $27(28.1)$ \\
Tidak (n,\%) & $69(71.9)$ \\
Kutu Rambut & \\
Ya (n,\%) & \\
Tidak (n,\%) & $45(46.9)$ \\
Ketombe & $51(53.1)$ \\
Ya (n,\%) & \\
Tidak (n,\%) & $26(27.1)$ \\
\hline
\end{tabular}

*IMT (indeks massa tubuh)

Hubungan yang sangat signifikan didapatkan pada kejadian keluhan kutu rambut dan ketombe dengan jenis kelamin $(\mathrm{p}<0,001)$ dengan proporsi terbesar pada jenis kelamin perempuan. Hal ini sejalan dengan penelitian yang dilakukan oleh Lukman dkk. di satu pondok pesantren di Jember dan Amelia dkk di suatu pondok pesantren di Palembang yang 
menemukan hubungan signifikan antara jenis kelamin dengan kejadian pediculosis capitis-penyakit kulit kepala akibat infestasi tungau (kutu)-secara berturut-turut sebanyak 98,5\% (p 0,00) dan 89,7\% (p<0,001). ${ }^{2021}$

Secara epidemiologi, infestasi Pediculus humanus capitis ini lebih sering ditemukan pada perempuan. ${ }^{22}$ Selain dapat karena kepadatan penghuni kamar atau ruangan yang sering menjadi salah satu penyebab masalah kesehatan di sekolah asrama ataupun di rumah, timbulnya infestasi kutu terutama pada perempuan didukung oleh adanya kecenderungan rambut panjang dan penggunaan bersama pakaian dan alat-alat pribadi seperti sisir, perlengkapan tidur, handuk, termasuk jilbab dan mukenah antarteman di sekolah/pesantren.9,12 Sebagai langkah pencegahan penyakit, dapat dilakukan dengan menghindari kontak kepala-ke-kepala saat beraktivitas serta penggunaan pakaian dan peralatan pribadi secara bergantian. Selain itu, bila ditemukan penderita infeksi maka pakaian dan barang-barang penderita sebaiknya dicuci dengan air panas $130 \mathrm{~F}$ atau disimpan dalam kantung plastic selama 2 minggu. Melakukan pengisapan debu di lantai dan perabotan rumah/kamar juga dapat dilakukan untuk mencegah re-infestasi kutu kembali ke manusia. ${ }^{25}$

Terkait keluhan ketombe yang dapat menjadi salah satu menifestasi penyakit dermatitis seboroik, pityriasis simplex capillitia, atau pityriasis $\operatorname{sicca}^{16}$, temuan penelitian ini juga didukung oleh penelitian Silvia dkk. di Bandar Lampung yang menemukan adanya hubungan signifikan antara jenis kelamin dengan kejadian dermatitis seboroik $(\mathrm{p}<0,008)$. Selain itu, penelitian oleh Gunathilaka dkk di Sri Lanka juga menemukan hubungan signifikan prevalensi penyakit kulit dengan jenis kelamin $(p=0,001)$ dengan kelainan terbanyak yakni pediculosis, ketombe, dan infeksi jamur. Penelitian tersebut juga menemukan bahwa rambut panjang, jumlah kamar yang terbatas, serta jumlah anggota keluarga yang besar merupakan faktor risiko terjadinya penyakit kulit tersebut pada anak sekolah. ${ }^{26}$ Selain itu, frekuensi keramas, penggunaan berbagai jenis shampoo, dan cara 
penggunaan handuk juga dikaitkan dengan kejadian dermatitis seboroik pada perempuan. $^{24}$

Sebagian besar penyakit kulit menular yang diamati dalam penelitian ini dapat dikendalikan dengan menjaga kebersihan diri dan sanitasi lingkungan, nutrisi yang memadai, mengurangi kepadatan ruangan, serta terus menggalakkan perilaku hidup bersih dan sehat baik di sekolah, di rumah, serta di manapun santri berada.

Tabel 2. Hubungan keluhan penyakit kulit dan kelamin dan jenis kelamin santri Pesantren Al Ikhlas Bone $(n=96)$

\begin{tabular}{|c|c|c|c|}
\hline \multirow{2}{*}{ Variabel } & \multicolumn{2}{|c|}{ Jenis Kelamin } & \multirow[t]{2}{*}{$\mathbf{P}$} \\
\hline & Laki-Laki, n(\%) & Perempuan, n(\%) & \\
\hline \multicolumn{4}{|l|}{ Gatal } \\
\hline Ya & $41(89.1)$ & $43(86.0)$ & 0.64 \\
\hline Tidak & $5(10.9)$ & $7(14.0)$ & \\
\hline \multicolumn{4}{|c|}{ Kemerahan } \\
\hline Ya & $27(58, .7)$ & $33(66.0)$ & 0.46 \\
\hline Tidak & 19(41.3) & $17(34.0)$ & \\
\hline \multicolumn{4}{|c|}{ Kulit bersisik } \\
\hline Ya & $22(47.8)$ & $25(50)$ & 0.83 \\
\hline Tidak & $24(52.2)$ & $25(50)$ & \\
\hline \multicolumn{4}{|l|}{ Bisul } \\
\hline Ya & 10(21.7) & $17(34)$ & 0.18 \\
\hline Tidak & $26(78.3)$ & $33(66)$ & \\
\hline \multicolumn{4}{|c|}{ Kutu rambut } \\
\hline Ya & $0(0)$ & $45(90)$ & $<0.001$ \\
\hline Tidak & $46(100)$ & $5(10)$ & \\
\hline \multicolumn{4}{|l|}{ Ketombe } \\
\hline Ya & $2(4.3)$ & $24(48.0)$ & $<0.001$ \\
\hline Tidak & $44(95.7)$ & $26(52.0)$ & \\
\hline
\end{tabular}

*Uji Chi Square

${ }^{* *} p<0.001$ adalah nilai $p$ signifikan kurang dari 0.00 


\section{SIMPULAN}

Sebanyak 85\% dan 62,5\% santri Pondok Pesantren Al Ikhlas Kabupaten Bone menderita keluhan gatal dan kemerahan pada kulit. Prevalensi infestasi kutu rambut dan ketombe berhubungan signifikan dengan jenis kelamin.

\section{Ucapan Terima Kasih}

Kami mengucapkan terima kasih kepada pihak pesantren Al Ikhlas, Kabupaten Bone. Yang memberikan sarana bagi pelaksanaan kegiatan pengabdian masyarakat Prodi Pendidikan Dokter FKIK UIN Alauddin serta Prodi Pendidikan Dokter FKIK UIN Alauddin yang telah mengalokasikan dana bagi pelaksanaan kegiatan ini.

\section{Referensi}

1. Kementerian Agama Republik Indonesia. Pangkalan Data Pondok Pesantren. 2019.

2. Peraturan Pemerintah Republik Indonesia Nomor 55 Tahun 2007. Pendidikan Agama dan Pendidikan Keagamaan. 2007.

3. Shofiyyah NA, Ali H, Sastraatmadja N. Model Pondok Pesantren di Era Milenial. BELAJEA J Pendidik Islam. 2019;4(1): 1.

4. Ikhwanudin A. Perilaku kesehatan santri : (studi deskriptif perilaku pemeliharaan kesehatan, pencarian dan penggunaan sistem kesehatan dan perilaku kesehatan lingkungan di pondok pesantren assalafi al fithrah, surabaya). J Unair. 2013;2(2): 120.

5. Rachmawaty FJ, Rosmelia, Rochmah FSN, Lusiyana N. Peran Rekestren (Relawan Kesehatan Pesantren) Dalam Meningkatkan Derajat Kesehatan Pondok Pesantren. 2018.

6. Guna AM, Amatiria G. Perilaku Hidup Bersih dan Sehat (PHBS) dalam Upaya Mencegah Penyakit Kulit pada Santri Di Pondok Pesantren Nurul Huda. J Keperawatan. 2015;XI(1): 7-14.

7. Widasmara D. Konsep Baru Skabies. Malang: UB Press; 2020.

8. Ibadurrahmi H, Veronica S, Nugrohowati N. Faktor-Faktor Yang Berpengaruh Terhadap Kejadian Penyakit Skabies Pada Santri Di Pondok Pesantren Qotrun Nada Cipayung Depok Februari Tahun 2016. J Profesi Med J Kedokt dan Kesehat. 2017;10(1): 33-45.

9. Natadisastra D, Ridad A. Parasitologi Kedokteran : Ditinjau dari organ tubuh yang diserang. Jakarta: Penerbit Buku Kedokteran EGC; 2009.

10. Murlistyarini S, Prawitasari S. Intisari Ilmu Kesehatan Kulit Kelamin. Malang: UB 
Press; 2018.

11. Yuniaswan A, Dearikha M. Infestasi Parasit dalam Dermatologi. Malang: UB Press; 2020.

12. Adrians, Yah AA. Keterkaitan antara sanitasi pondok pesantren dengan kejadian penyakit yang dialami santri di Pondok Pesantren Sunan Drajat. Med Technol Public Heal J. 2017;1(1): 4-13.

13. Ni'mah N. Hubungan Perilaku Personal Hygiene dengan Kejadian Scabies pada Santri Putra dan Putri di Pondok Pesantren An-Nur Ngrukem Sewon Bantul Yogyakarta. Universitas 'Aisyiyah Yogyakarta. 2016.

14. Aisyah S. Analisis Pelaksanaan Program Pos Kesehatan Pesantren (Poskestren) Dalam Menghadapi Penyakit Skabies Di Pondok Pesantren Al-Aziziyah Lombok Barat Provinsi Nusa Tenggara Barat. Universitas Hasanuddin. 2017.

15. Siregar FK. Prevalensi Penyakit Kulit Akibat Infeksi Parasit yang Sering Terjadi di Pesantren Darul Hikmah Medan. Universitas Muhammadiyah Sumatera Utara. 2018.

16. Callen JP, Horn TD, Mancini AJ, Salasche SJ, Schaffer J V, Schwarz T, et al. Dermatology. In: Bolognia JL, Jorizzo JL, Rapini RP, editors. 4th ed. USA: Elsevier Ltd; 2017. p. 91-95;197-199;1295-1297.

17. Mading M, Indriaty I. Kajian Aspek Epidemiologi Skabies pada Manusia. J Penyakit Bersumber Binatang. 2015;2(2): 9-18.

18. Sungkar S. Skabies: Etiologi, Patogenesis, Pengobatan, Pemberantasan, dan Pencegahan. Jakarta: Badan Penerbit FKUI; 2016.

19. Machfutra ED, Noor A, Luxiarti R, Mutmainah NF. Hygienic and Healthy Behaviour of Female Islamic Boarding House. Bul Penelit Sist Kesehat. 2018;21: 1410 2935.

20. Lukman N, Armiyanti Y, Agustina D. Hubungan Faktor-Faktor Risiko Pediculosis capitis terhadap Kejadiannya pada Santri di Pondok Pesantren Miftahul Ulum Kabupaten Jember. Digit Repos Univ Jember. 2018;4(2): 102-9.

21. Amelia L, Anwar C, Wardiansyah. Association of Students' Sociodemographic, Knowledge, Attitude and Practice with Pediculosis capitis in Pondok Pesantren Tahfidzil Qur'an Yayasan Tijarotal Lan Tabur Palembang, Indonesia. Biosci Med. 2019;3(1): 51-63.

22. Callen JP, Horn TD, Mancini AJ, Salasche SJ, Schaffer J V, Schwarz T, et al. Dermatology. In.

23. Arsinta D, Anwar C, Ramdja M. Association of Sharing Materials with Pediculosis Capitis in Students of Pondok Pesantren Tahfidzil Qur' an Yayasan Tijarotal Lan Tabur Palembang. Maj Kedokt Sriwij. 2019;51(3): 155-63.

24. Ayu B, Indrastiti R, Ratnaningrum K. Hubungan Perilaku Perawatan Rambut Terhadap Kejadian Dermatitis Seboroik pada Siswi SMA Muhammadiyah 1 Semarang. Magna Medica J Berk Ilm Kedokt Kesehat. 2018;2(4): 76-84.

25. CDC. Parasites - Lice. US Department of Health and Human Services. 2019. 
26. Gunathilaka N, Chandrasena N, Udayanga L. Prevalence of Ectoparasitic Infections and Other Dermatological Infections and Their Associated Factors among School Children in Gampaha District, Sri Lanka. Can J Infect Dis Med Microbiol. 2019; 